\title{
Past and present land use influences on tropical riparian zones: an isotopic assessment with implications for riparian forest width determination
}

\author{
Luiz Felippe Salemi ${ }^{1,5,6}$, Silvia Rafaela Machado Lins ${ }^{1}$, Elizabethe de Campos Ravagnani ${ }^{I}$ \\ Marcelo Magioli ${ }^{2}$, Melissa Gaste Martinez ${ }^{1}$, Fernando Guerra ${ }^{3}$, Natassia Bonini Vidas ${ }^{1}$, Aline Fransozi ${ }^{4}$, \\ Silvio Frosini de Barros Ferraz ${ }^{4}$ \& Luiz Antonio Martinelli ${ }^{l}$ \\ ${ }^{1}$ Universidade de São Paulo, Centro de Energia Nuclear na Agricultura, Laboratório de Ecologia Isotópica, \\ Piracicaba, SP, Brazil. \\ ${ }^{2}$ Laboratório de Ecologia, Manejo e Conservação de Fauna Silvestre, Universidade de São Paulo, \\ Escola Superior de Agricultura "Luiz de Queiroz", Ciências Florestais \\ Av. Pádua Dias, 11, 13418-900, Piracicaba, SP, Brazil. \\ ${ }^{3}$ Universidade de São Paulo, Centro de Energia Nuclear na Agricultura, Laboratório de \\ Fertilidade do Solo, Piracicaba, SP, Brazil. \\ ${ }^{4}$ Laboratório de Hidrologia Florestal, Universidade de São Paulo, Escola Superior de Agricultura \\ "Luiz de Queiroz", Ciências Florestais, Av. Pádua Dias, 11, 13418-900, Piracicaba, SP, Brazil. \\ ${ }^{5}$ Universidade de Brasília, Faculdade de Planaltina, Divisão de Ciências da Vida e da Terra, \\ Brasília, DF, Brazil. \\ ${ }^{6}$ Corresponding author: Luiz Felippe Salemi, e-mail: Ifsalemi@unb.br
}

SALEMI, L.F., LINS, S.R.M., RAVAGNANI, E.C., MAGIOLI, M., MARTINEZ, M.G., GUERRA, F., VIDAS, N.B., FRANSOZI, A., FERRAZ, S.F.B., MARTINELLI, L.A. Past and present land use influences on tropical riparian zones: an isotopic assessment with implications for riparian forest width determination. Biota Neotropica. 16(2): e20150133. http://dx.doi.org/10.1590/1676-0611-BN2015-0133

Abstract: In this article, by using carbon stable isotopes, we assessed the past and present land use influences that riparian areas are subject within agricultural landscapes. Emphasis is given to the understanding of the effects of the 2012 Brazilian Forest Act on such areas. We selected five riparian areas within a highly $\mathrm{C}_{4}$ dominated agricultural landscape. Three of them had 30 meters native riparian forest buffer (NRFB) and two of them had 8 meter and no NRFB. We used three 100 meter-transects located 5 , 15 and 30 meters relative to stream channel to obtain soil samples $(0-10 \mathrm{~cm})$. All riparian areas presented soil carbon isotopic signatures that are not $\mathrm{C}_{3}$ (native forests) irrespective of having or not 30 meters NRFB. Two cases presenting less than 30 meters NRFB had higher $\mathrm{C}_{4}$ derived carbon contribution. All of the other three areas that followed the 30 meters NRFB presented, to some degree, $\mathrm{C}_{4}$ derived carbon, which was attributed to $\mathrm{C}_{4}$ organic matter deposition originated from cultivated areas and, in one case, to the persistence of former exotic grasses. With the 2012 Forest Act allowing narrower buffers ( $<30$ meters), we expect $\mathrm{C}_{4}$ contributions to soil organic matter to remain high in riparian areas and streams within agricultural landscapes dominated by $\mathrm{C}_{4}$ plants where 30 meter NRFB is no longer required. Such contributions will likely continue to have detrimental effects on stream water quality and biota.

Keywords: Watershed; Soil degradation; Organic matter; Sediment; Carbon cycling.

SALEMI, L.F., LINS, S.R.M., RAVAGNANI, E.C., MAGIOLI, M., MARTINEZ, M.G., GUERRA, F., VIDAS, N.B., FRANSOZI, A., FERRAZ, S.F.B., MARTINELLI, L.A. Influências pretéritas e presentes do uso da terra sobre zonas ripárias tropicais: uma avaliação isotópica com implicações para a determinação da largura de florestas ripárias. Biota Neotropica. 16(2): e20150133. http://dx.doi.org/10. 1590/1676-0611-BN-2015-0133

Resumo: Neste artigo, ao utilizar isótopos estáveis de carbono, nós avaliamos as influências presentes e pretéritas do uso da terra a que as áreas ripárias estão sujeitas quando situadas dentro de paisagens agrícolas. Ênfase é dada ao entendimento dos efeitos do Código Florestal de 2012 em tais áreas. Nós selecionamos cinco áreas ripárias em uma paisagem agrícola altamente dominada por plantas $\mathrm{C}_{4}$. Três delas apresentam faixa ripária de floresta nativa (FRFN) de 30 metros de largura e as outras duas apresentam FRFN de 8 e $0 \mathrm{~m}$ (i.e. sem FRFN). Nós utilizamos três transectos de 100 metros localizados a 5, 15 e 30 metros de distância do canal fluvial para obter amostras de solo $(0-10 \mathrm{~cm})$. Todas as áreas ripárias apresentaram assinaturas isotópicas do carbono do solo que não são $\mathrm{C}_{3}$ (floresta nativa) 
independentemente de apresentarem ou não FRFN de 30 metros. Os dois casos em que FRFN era menor que $30 \mathrm{~m}$ apresentaram maior contribuição de carbono oriundo de plantas $\mathrm{C}_{4}$. Todas as outras três áreas com FRFN de $30 \mathrm{~m}$ também apresentaram, em algum grau, carbono oriundo de plantas $\mathrm{C}_{4}$. Todas as outras três áreas com FRFN de $30 \mathrm{~m}$ também apresentaram, em algum grau, carbono oriundo de plantas $\mathrm{C}_{4}$ que foi atribuído à deposição de matéria orgânica de plantas $\mathrm{C}_{4}$ originada das áreas cultivadas e, em um caso, à persistência de gramíneas exóticas pré-existentes. Com o Código Florestal de 2012 permitindo FRFN mais estreitas ( $<30$ metros), nós esperamos que a contribuição de plantas $\mathrm{C}_{4}$ para a matéria orgânica permaneça alta em áreas ripárias e rios dentro de paisagens agrícolas dominadas por plantas $\mathrm{C}_{4}$ onde a FRFN de $30 \mathrm{~m}$ não é mais uma obrigação. Tais contribuições irão, provavelmente, continuar a ter efeitos prejudiciais à qualidade de água dos rios e à sua biota.

Palavras-chave: Bacia hidrográfica; Degradação do solo; Matéria orgânica; Sedimento; Ciclagem de carbono.

\section{Introduction}

Riparian ecosystems generally perform many important ecological processes. When these streamside ecosystems are under forest cover these areas are considered to be important due to a series of reasons: (i) protection of stream banks against erosion and bank sliding (Abernethy \& Rutherford 2000); (ii) reduction of erosion and input of soil particles into the stream (Lowrance et al. 1986, Verstraeten et al. 2006, Pires et al. 2009); (iii) shading and reduction of the water temperature (important for fish reproduction) (Imholt et al. 2013); (iv) riparian forests provide nutrients and carbon to aquatic communities (Lowrance et al. 1985); and they might also increase the input of coarse woody debris to the stream channel, which is important in creating habitat diversity within the stream environment (De Paula et al. 2011). These attributes of riparian forests are especially important in watersheds dominated by upland agricultural fields, where soil disturbance by cultivation and use of fertilizers and agrochemicals are frequent.

Several studies have shown that the width of the riparian forest is an important characteristic regarding some of the aforementioned attributes (Wenger, 1999, Zhang et al., 2010). Using meta-analysis, Zhang et al. (2010) showed that in order to perform these processes, at least a width of $20 \mathrm{~m}$ is required, although, depending on the attributes in view, different widths might be required (for more details, see Wenger 1999, Sparovek et al. 2002, Hawes \& Smith 2005, Yuan et al. 2009). However, if all these important processes are to be achieved in a single place at the same time, the process that requires a wider buffer might be the one that should be adopted.

In Brazil, riparian areas are protected by law according to the Forest Act that is the Brazilian federal legislation that regulates the presence and distribution of the minimal native forest cover within rural private properties. This Act was originally created in 1934 and it was reformulated in 1965. Such Act stipulated that surface water bodies should have a riparian buffer around them to guarantee soil, water, biodiversity resources conservation and ecosystem processes. In the case of small streams ( $>10$ meters wide), the riparian buffer should present a minimum of $30 \mathrm{~m}$ and springs should have a 50 -meter buffer. These two buffers are denominated 'permanent preservation areas' in the Brazilian Forest Act and should be under the native vegetation cover (i.e. riparian forests) in order to guarantee their conservation goal.

In 2012, the Brazilian Congress approved a series of changes in the aforementioned Forest Act allowing the decrease of the width of riparian buffers needed to be restored in rural properties in cases where the law had not been followed. This led to the reduction, in many cases, of the riparian buffers around small streams. For instance, the riparian buffer width in the 2012 Forest Act might be of only 5 meters instead of the 30 meters previously stablished in the 1965 Forest Act.

In São Paulo State, the most economically developed state of Brazil, rural areas are intensively used and currently dominated by $\mathrm{C}_{4}$ plants such as sugarcane and tropical forage grass species (Rudorff et al. 2010, Adami et al. 2012), whereas forest remnants are generally dominated by $\mathrm{C}_{3}$ plants. These two types of photosynthetic pathways generate different carbon isotopic composition (Farqhuar et al. 1989). $\mathrm{C}_{3}$ plants generally have a $\delta^{13} \mathrm{C}$ around $-28 \%$, which is lower compared to $-12 \%$ which is the $\delta^{13} \mathrm{C}$ average value for $\mathrm{C}_{4}$ plants (Farqhuar et al. 1989). Therefore, carbon isotopic composition of the soil organic matter is highly influenced by vegetation cover (Zhang et al. 2015). This fact allows the use of carbon stable isotopes to track the source of organic matter $\left(\mathrm{C}_{3}\right.$ versus $\mathrm{C}_{4}$ ) and relate it to land-cover (Martinelli et al. 1996).

In this study, we used carbon isotopic signature of the surface soil organic matter in order to investigate past and present land use influences on riparian areas of small agricultural watersheds in Southeast Brazil. Although the findings of this study are specific to the studied watersheds, we advocate here that the carbon isotopic signature of soil organic matter can be used as a proxy of the Forest Act compliance anywhere in the country in cases where the original forest was replaced by $\mathrm{C}_{4}$ plants (forage grasses, sugarcane and corn). We chose five small watersheds to conduct this study; three of them were in compliance with the Forest Act regarding the width of the riparian forest; and in two of these watersheds the riparian forest width was less than 10 meters.

\section{Material and Methods}

\section{Study areas}

The selection of the areas was based on finding agricultural areas dominated by $\mathrm{C}_{4}$ crops with possible influence of $\mathrm{C}_{4}$ derived carbon on riparian areas, which, at least initially, would be expected to present a dominance of $\mathrm{C}_{3}$ signal when under forest. Five first order streams and their respective watersheds belonging to the Piracicaba river basin (Southeast Brazil) were selected (Table 1; Figure 1). This is an important agricultural region of the country mainly due to the extensive sugarcane fields, with several sugar-ethanol mills in the region.

According to the Köppen classification, the climate is subtropical (Cwa), with a distinct dry season (April to September; mean monthly temperature of $20^{\circ} \mathrm{C}$ and an average 
Table 1. Location and land use in the riparian areas of the five small watersheds.

\begin{tabular}{|c|c|c|c|c|c|}
\hline \multirow{2}{*}{$\begin{array}{c}\text { Watershed } \\
1\end{array}$} & \multirow{2}{*}{$\begin{array}{c}\text { Municipality } \\
\text { Piracicaba }\end{array}$} & \multicolumn{2}{|c|}{ Coordinates } & \multirow{2}{*}{$\begin{array}{c}\text { Land-use } \\
\text { Sugarcane }\end{array}$} & \multirow{2}{*}{$\begin{array}{c}\begin{array}{l}\text { Riparian forest buffer } \\
\text { width }(\mathbf{m})\end{array} \\
\sim 8\end{array}$} \\
\hline & & $2236^{\prime} 44.82^{\prime \prime} \mathrm{S}$ & $4740^{\prime} 19.76^{\prime \prime} \mathrm{O}$ & & \\
\hline 2 & Piracicaba & $22^{\circ} 43^{\prime} 32.03^{\prime \prime S}$ & $47^{\circ} 31^{\prime} 29.11^{\prime \prime O}$ & Pasture & Absent \\
\hline 3 & Limeira & $22^{\circ} 30^{\prime} 33^{\prime \prime} \mathrm{S}$ & $47^{\circ} 15^{\prime} 12^{\prime \prime} \mathrm{O}$ & Citrus/Pasture & 30 \\
\hline 4 & Piracicaba & $22^{\circ} 29^{\prime} 54.49^{\prime \prime} \mathrm{S}$ & $47^{\circ} 41^{\prime} 1.67^{\prime \prime O}$ & Sugarcane & 30 \\
\hline 5 & Piracicaba & $2237^{\prime} 02.91 " \mathrm{~S}$ & $4740^{\prime} 04.76^{\prime \prime} \mathrm{O}$ & Sugarcane & 30 \\
\hline
\end{tabular}
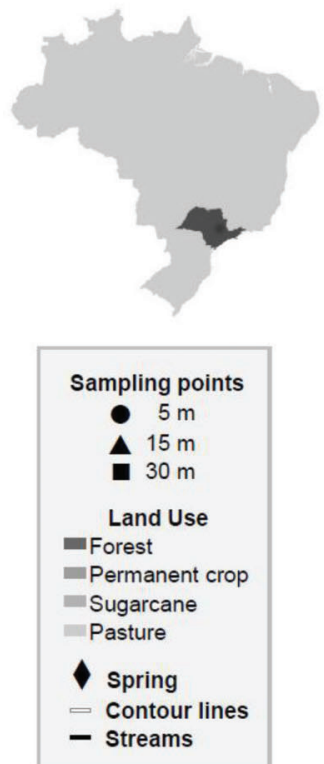

$$
\text { N }
$$

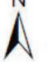

$1: 1.500$

Projection System: UTM SAD69 - Zone 235

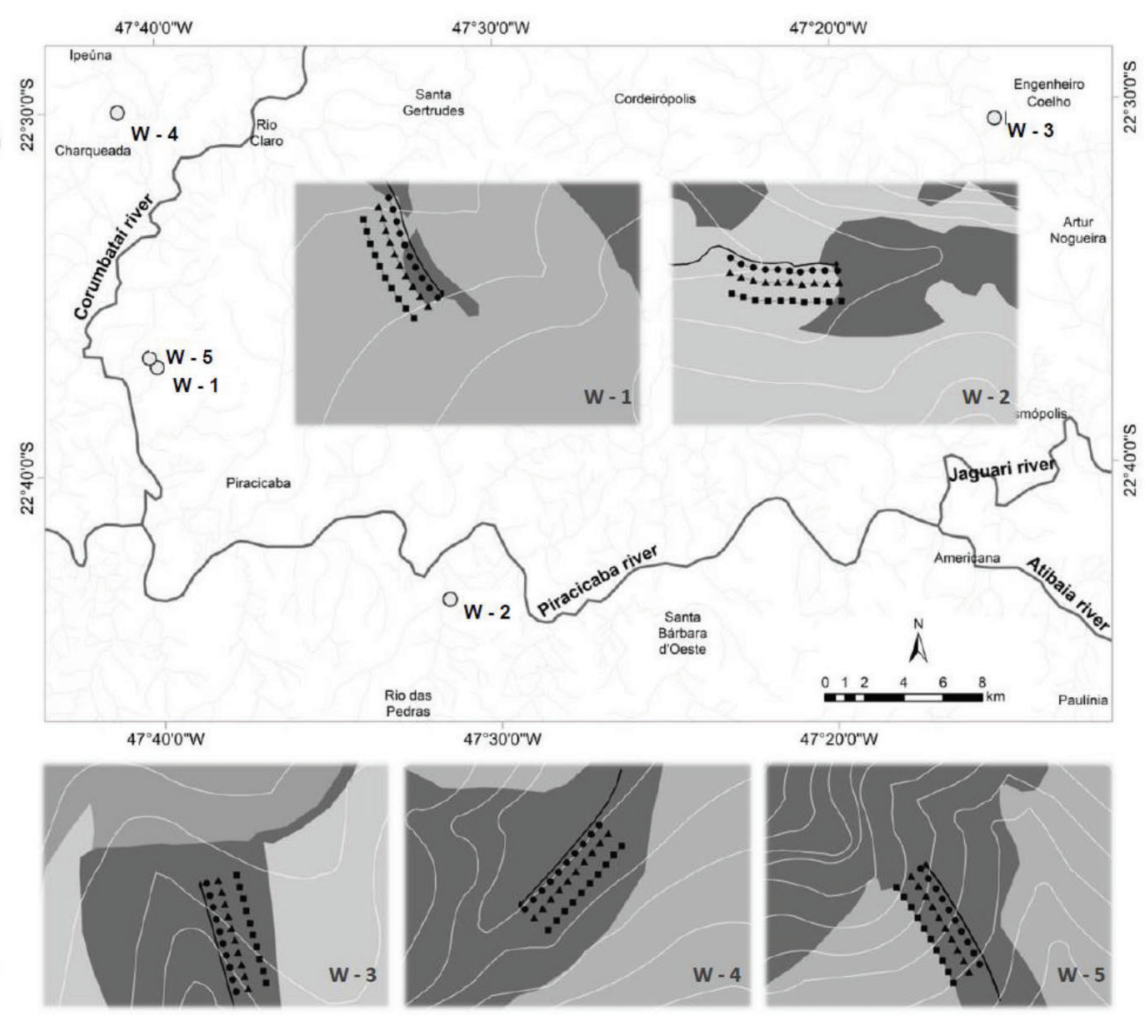

Figure 1. Five riparian areas within the five small watersheds (W). Dark areas within W-1 to 5 indicate forest $\left(\mathrm{C}_{3}\right)$ cover whereas ligher colours indicate $\mathrm{C}_{4}$ cover. Black circles, triangles and quadrats indicate soils sampling points in linear transects located 5,15 and 30 meters relative to stream channel. Scale on the bottom left corner refers to watersheds images whereas scale on the right, above W-5 image, refers to the map.

relative humidity of around $70 \%$ ) and wet season (October to March; mean monthly temperature of around $24.4{ }^{\circ} \mathrm{C}$ and relative humidity around $80 \%$ ). The annual rainfall in the region is approximately $1,400 \mathrm{~mm}$, and the mean annual temperature is approximately $22^{\circ} \mathrm{C}$.

All five small watersheds are within the domain of the Atlantic Forest biome. According to local farmers, the watersheds of streams 1 and 5 were converted to cornfields around the 1930s and after 20 years, corn was converted to sugarcane. Although these two watersheds are very close geographically, they present very different riparian forest cover patterns, being around 5 to 10 meters in the former, and 30 meters wide in the latter. In the watershed 2, pasture has been established for at least 13 years without any riparian forest left. Watersheds of streams 3 and 4, in turn, were covered by pasture and pasture and sugarcane, respectively, for at least 10 years with riparian forest buffer of 40 meters or more (Figure 1). In the watershed 3, interviews with local farmers revealed that the riparian area had been under pasture (Andropogon bicornis L.) until 1988. After that, forest restoration practices took place and the area was recovered by native forest again as it is at the present moment.

Soils in four of the five riparian areas are generally classified as Ultisols (Udults); the only exception is in the riparian area of watershed 4 in which the soil is classified as an Oxisol (Udox). The topography is generally formed by gentle slopes $(\sim 8 \%)$ in areas under Ultisol soil type, and under gentle to flat slopes $(\sim 3 \%)$ in the watershed 4 .

\section{Sampling design}

In order to investigate the presence of carbon from $\mathrm{C}_{4}$ plants, three $100-\mathrm{m}$ transects were established parallel to the stream channels at a distance of 5, 15 and 30-m from to the stream channel (Figure 1). Each transect started from the spring to 100 meters downstream. Soil samples were obtained every 10 meters in each transect totaling 10 soil samples per transect. The sampling procedure was made by using Dutch augers to collect soil samples from 0 to $10 \mathrm{~cm}$ soil layer as 
adopted elsewhere (Powers \& Schlesinger 2002). Soil samples were collected from April to June 2011.

\section{Soil analysis}

Soil samples were previously air-dried and then sieved to $<2 \mathrm{~mm}$ in order to remove rocks, roots, leaves and charcoal. A sub-sample of $10 \mathrm{~g}$ of each sample was obtained using a Jones splitter. Afterwards, it was homogenized and milled. Finally, $5 \mathrm{mg}$ of this sub-sample was weighed and packed separately into tin capsules.

The ${ }^{13} \mathrm{C}:{ }^{12} \mathrm{C}$ ratio was determined using a mass spectrometer, Delta Plus from Finnigan Mat, and the isotopic ratio was reported as $\delta^{13} \mathrm{C}$ (\%) notation using the following equation:

$$
\delta^{13} \mathrm{C}(\% \mathrm{o})=1000 *\left[\left(\mathrm{R}_{\text {sample }}-\mathrm{R}_{\text {standard }}\right) /\left(\mathrm{R}_{\text {standard }}\right)\right]
$$

Where:

$\delta^{13} \mathrm{C}$ : is the abundance of ${ }^{13} \mathrm{C}$ in the sample

$\mathrm{R}$ sample: is the sample ${ }^{13} \mathrm{C}:{ }^{12} \mathrm{C}$ ratio

$\mathrm{R}$ standard: is the standard ${ }^{13} \mathrm{C}:{ }^{12} \mathrm{C}$ ratio

The precision for carbon isotope was obtained by running an internal standard and it was $0.2 \%$.

We assumed that organic matter derived from $\mathrm{C}_{3}$ plants has $\delta^{13} \mathrm{C}$ value equal to $-27.9 \%$ which is the lowest $\delta^{13} \mathrm{C}$ measured in our five study areas, and plant organic matter derived from $\mathrm{C}_{4}$ plants has a $\delta^{13} \mathrm{C}_{4}$ as $-11.3 \%$ based on an broad isotopic analysis carried out in Brazil available elsewhere (see Assad et al. 2013). The percentage contribution from $\mathrm{C}_{4}$-derived carbon is given by the following isotope dilution equation:

$$
\mathrm{C}_{4}(\%)=\left(\delta^{13} \mathrm{C}_{\text {soil }}-\delta^{13} \mathrm{C}_{3}\right) /\left(\delta^{13} \mathrm{C}_{4}-\delta^{13} \mathrm{C}_{3}\right)
$$

Where:

$\delta^{13} \mathrm{C}_{\text {soil }}$ is the carbon isotopic composition of the soil organic matter;

$\delta^{13} \mathrm{C}_{3}$ is the carbon isotopic composition of $\mathrm{C}_{3}$ vegetation $(-27.9 \%)$; and

$\delta^{13} \mathrm{C}_{4}$ is the carbon isotopic composition of $\mathrm{C}_{4}$ vegetation $(-11.3 \%)$.

\section{Results}

The two riparian area with low or null forest cover (watersheds 1 and 2) had soil $\delta^{13} \mathrm{C}$ values predominantly higher than $-17 \%$, some reaching values as high as $-12 \%$, denoting a high contribution of $\mathrm{C}_{4}$ derived organic matter to the soil (Figure 2a, b). In the watershed 1, even the 5-m sampling points that are located within the riparian forest remnant had approximately $75 \%$ of organic carbon derived from $\mathrm{C}_{4}$ plants, suggesting that the entire riparian zone had influence of $\mathrm{C}_{4}$ plants (Table 2). In the riparian area of the watershed 2, the $\delta^{13} \mathrm{C}$ of the soil near the spring resembled those values of $\mathrm{C}_{3}$ vegetation, being lower than $-24 \%$. After that, a marked downstream increase in the soil $\delta^{13} \mathrm{C}$ values in all three transects were observed, with values predominantly higher than $-18 \%$, denoting a clear dominance of $\mathrm{C}_{4}$ derived carbon (Figure 2b). In these transects, with the exception of the spring, the average $\mathrm{C}_{4}$ derived carbon contribution was approximately $70 \%$ (Table 2 ).
In the watersheds 3,4 and 5 forest covers more than $30 \mathrm{~m}$ of the riparian area (Figure $2 \mathrm{~b}$ to $2 \mathrm{~d}$ ). Although there is the dominance of $\mathrm{C}_{3}$ vegetation cover, only the watershed 5 soil showed a clear soil $\delta^{13} \mathrm{C}$ values resembling those typical of $\mathrm{C}_{3}$ vegetation cover. In this watershed, soil samples collected along the $5-\mathrm{m}$ transect line had $\delta^{13} \mathrm{C}$ values varying from approximately $-28 \%$ to $-25 \%$, typically within the $\mathrm{C}_{3}$ plants range values (Figure 2e). Soil $\delta^{13} \mathrm{C}$ values were higher in the other two transects of watershed 5 , but with few values higher than $-22 \%$, evidencing a low contribution of $\mathrm{C}_{4}$ plants to the soil in this watershed (Table 2). In the riparian areas of watershed 3 , $\delta^{13} \mathrm{C}$ values were lower than $-24 \%$ from 0 to 20 meters, increasing to values varying from -24 to $-18 \%$ in the middle portion of the transect (from 20 to 70 meters). In the final part of the transect (from 70 to $100 \mathrm{~m}$ ), soil $\delta^{13} \mathrm{C}$ values decrease again to values lower than $-24 \%$ (Figure 2). Therefore, there was a low $\mathrm{C}_{4}$ contribution to the soil organic matter in the portion closer to the spring and in the final portion of the transect. Finally, the soil $\delta^{13} \mathrm{C}$ of riparian areas of watershed 4 varied between -22 to $-16 \%$ along the transect, suggesting a mixture in different proportions of $\mathrm{C}_{3}$ and $\mathrm{C}_{4}$ vegetation (Figure 2d). Lower $\delta^{13} \mathrm{C}$ values were observed in the $5 \mathrm{~m}$ transect line with values varying from -22 to $-20 \%$ o in the first 60 meters, and increasing to approximately $-18 \%$ in the final 40 meters of the transect, denoting an increase in the contribution of $\mathrm{C}_{4}$ derived organic matter in this last portion of the transect (Table 2). The soil $\delta^{13} \mathrm{C}$ values observed in the $15 \mathrm{~m}$-transect line varied from -18 to $-16 \%$ in the entire transect, while values increased to approximately $-16 \%$ in the $30 \mathrm{~m}$-transect line. The average $\mathrm{C}_{4}$ contribution along the $5 \mathrm{~m}$-transect line was $44 \%$, increasing to 66 to $69 \%$ in the $15 \mathrm{~m}$ and $30 \mathrm{~m}$-transect lines, respectively (Table 2 ).

\section{Discussion}

\section{$\delta^{13} C$ variability within riparian areas}

There was no forest left in the majority of riparian area of watershed 2 that since 2002 has been covered by $\mathrm{C}_{4}$ grass forage. Only around the spring, the $\mathrm{C}_{3}$ contribution to the soil increases due to the proximity of remnant forest immediately upslope the spring. In the rest of the transect, forest $\left(C_{3}\right)$ is practically absent and there is no litter layer on the soil surface. In this case, the vegetation cover and the soil organic matter have similar $\delta^{13} \mathrm{C}$ values, and this area is clearly in no compliance with the Forest Act.

The watershed 1 forest cover width is wider than watershed 2 forest cover, reaching an average of 8 meters. The soil $\delta^{13} \mathrm{C}$ in this area $\left(5 \mathrm{~m}\right.$-transect) does not reflect the $\delta^{13} \mathrm{C}$ of the forest, but instead the $\delta^{13} \mathrm{C}$ of a $\mathrm{C}_{4}$ vegetation, suggesting that this forest is a young secondary growth that did not yet contributed substantially to the soil organic matter (Marin-Spiotta et al. 2009) or that upland $C_{4}$ influences within this area are substantial due to $\mathrm{C}_{4}$ organic matter deposition (Pires et al. 2009). The soil $\delta^{13} \mathrm{C}$ of the $15 \mathrm{~m}$ and $30 \mathrm{~m}$-transect lines reflect the $\mathrm{C}_{4}$ vegetation type. This riparian area is not also complying with the Forest Act.

In the riparian area of watershed 5 (with a forest cover 30 meters wide), the $\delta^{13} \mathrm{C}$ of the soil showed an unequivocal $\mathrm{C}_{3}$ signal. Therefore, there is a full compliance of this riparian area with the Forest Act. On the other hand, it seems also that the $30 \mathrm{~m}$-riparian buffer zone has been effective in avoiding the 
A

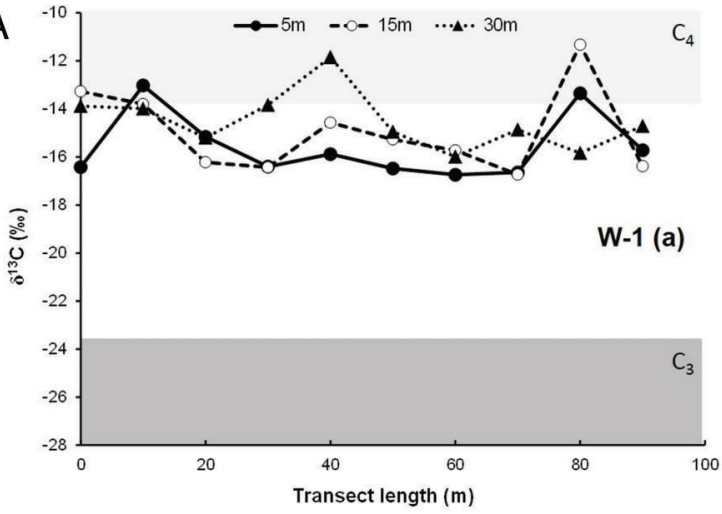

$\mathrm{C}$
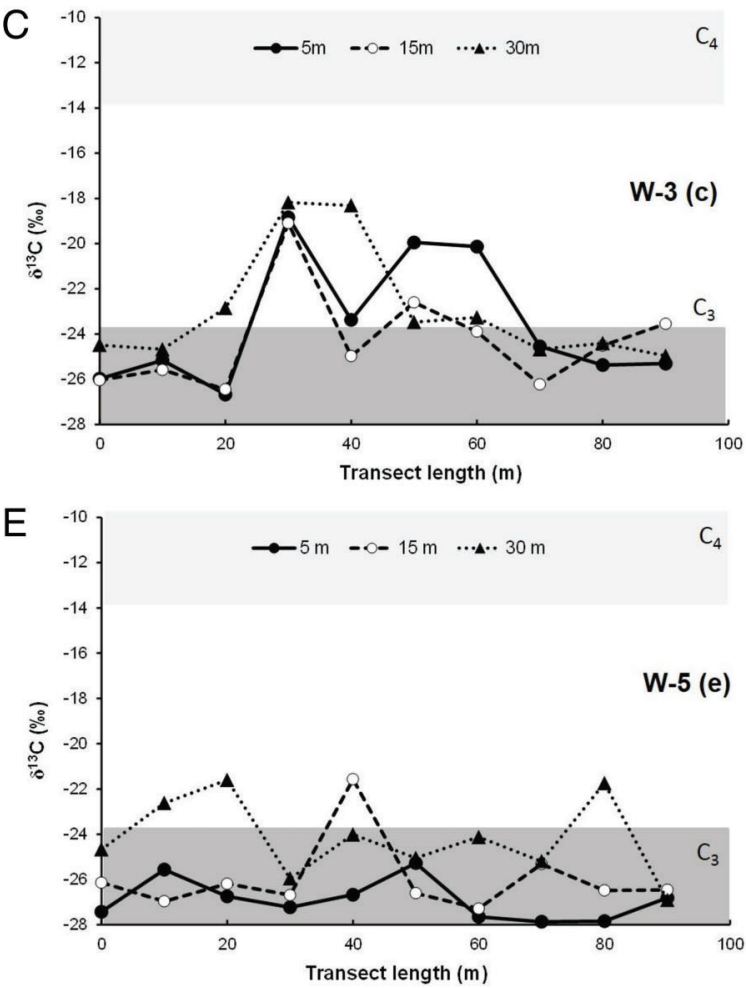

B
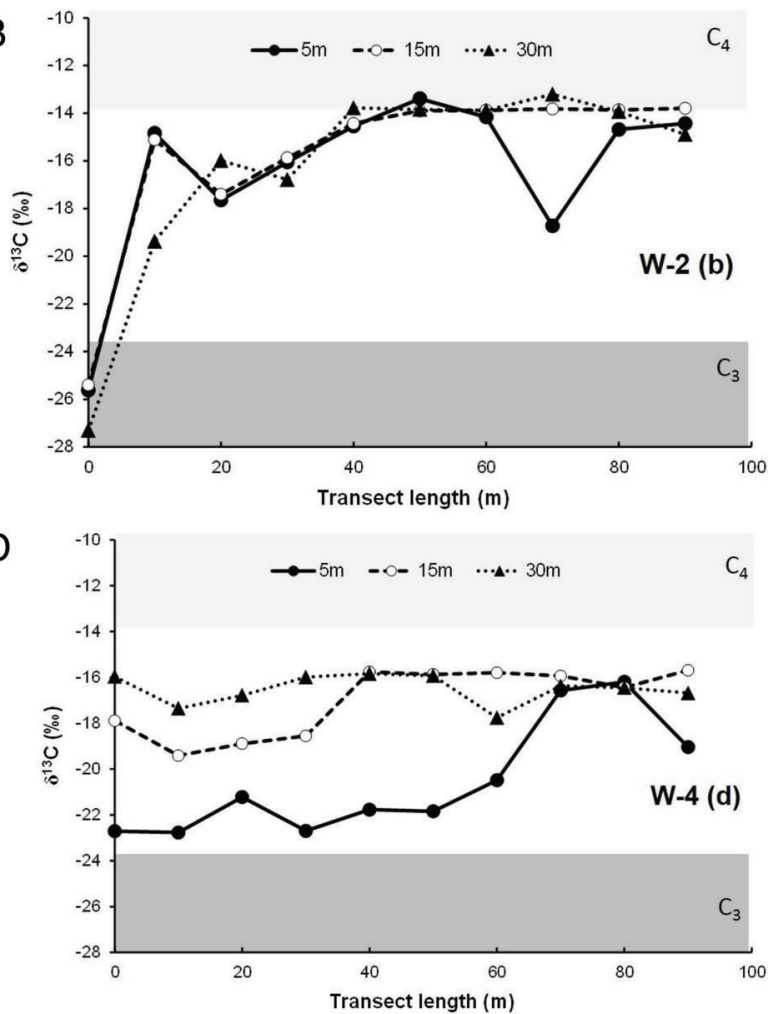

Figure 2. $\delta^{13} \mathrm{C}$ variation throughout the 5,15 and $30 \mathrm{~m}$ transects in the W-1 (a), W-2 (b), W-3 (c), W-4 (d) and W-5 (e). The top rectangles in the light grey indicates the expected area for $\mathrm{C}_{4}$ signals while the bottom rectangles in dark grey indicates the expected area for $\mathrm{C}_{3}$ signals. Middle rectangle in white indicates a region of a likely mixture of both photosynthetic types.

Table 2. Contribution (\%) of $\mathrm{C}_{4}$ derived carbon in each of the transects within the five small watersheds (W).

\begin{tabular}{|c|c|c|c|c|c|c|}
\hline \multirow[b]{3}{*}{$\mathbf{W}$} & \multicolumn{6}{|c|}{ Transects } \\
\hline & \multicolumn{2}{|c|}{$5 \mathrm{~m}$} & \multicolumn{2}{|c|}{$15 \mathrm{~m}$} & \multicolumn{2}{|c|}{$30 \mathrm{~m}$} \\
\hline & Mean & S.D. & Mean & S.D. & Mean & S.D. \\
\hline 1 & 74 & 8 & 78 & 11 & 81 & 7 \\
\hline 2 & 69 & 22 & 73 & 22 & 70 & 26 \\
\hline 3 & 26 & 17 & 22 & 13 & 30 & 15 \\
\hline 4 & 44 & 15 & 66 & 9 & 69 & 4 \\
\hline 5 & 6 & 5 & 11 & 10 & 22 & 11 \\
\hline
\end{tabular}

*S.D.: standard deviation

entrance of upland $\mathrm{C}_{4}$ carbon in the riparian given the higher contribution of $\mathrm{C}_{4}$ derived organic matter in the 30 -m transect.
The riparian area of the watershed 3 is also covered with forest $30 \mathrm{~m}$ wide; however, this area was entirely covered by $\mathrm{C}_{4}$ forage grasses until $\sim 25$ years ago when it was left for recover. Based on the soil $\delta^{13} \mathrm{C}$ values, it seems that the $\mathrm{C}_{3}$ vegetation replaced the old $\mathrm{C}_{4}$ forage only in the first and final part of the transect. It seems that in the middle, the signal of $\mathrm{C}_{4}$ vegetation of the old pasture still remains in the soil. Alternatively, the origin of this $\mathrm{C}_{4}$ material present in the middle of the transect could be generated upland by soil erosion and further deposition in this area. Several studies have documented the strong deposition rates of overland-flow derived materials within riparian areas, especially in flow convergence zones (i.e. depressions) (Lowrance et al. 1986, Cooper et al. 1987, Cavalcanti \& Lockaby 2005, Cavalcanti \& Lockaby 2006, Schoonover et al. 2006, Pires et al. 2009, Kreutzweiser et al. 2009, Mamoli et al. 2012). Moreover, there is the fact that tussocks of this grass were observed in the forest during our 
field campaigns, suggesting that this $\mathrm{C}_{4}$ signal might be derived from this persistent grass species (Guarantini et al. 2008, Griscom et al. 2009, Brancalion et al. 2009). The same is true for the riparian area of the watershed 4 that also has a large forest area wider than 30 meters, but still shows a clear $\mathrm{C}_{4}$ sign in the soil, which could be generated upland or be a remnant of the old pasture.

Another point that has to be mentioned is related to riparian forest age. The younger the riparian forest, the weaker would be the $\mathrm{C}_{3}$ signal in soil organic matter (Marin-Spiotta et al. 2009). Provided that most of riparian forests presented here are riparian forest remnants (watersheds 1, 4 and 5), no in situ influence (i.e. soil organic matter replacement by direct land use in the area) was responsible for our results. Even at watershed 3 , which has a $\sim 25$ years old riparian forest, the course of recovery towards a $\mathrm{C}_{3}$ signal can be seen in most parts of the transects. This is in accordance with findings that show that soils dominated by $\mathrm{C}_{4}$ organic matter became dominated by $\mathrm{C}_{3}$ organic matter within approximately 10 years after reforestation (Cook et al. 2014).

\section{Soil organic matter: proportion of $C_{4}$ derived carbon}

A study carried out in the same municipality of the present study (i.e. Piracicaba, São Paulo State, Brazil) showed that 50 years after a land-use conversion from forest $\left(C_{3}\right)$ to sugarcane $\left(\mathrm{C}_{4}\right)$, the soil under sugarcane still had approximately $40 \%$ of soil organic matter derived from forest (Vitorello et al. 1989). In other areas, a similar persistence of the $\mathrm{C}_{3}$ vegetation in the soil organic matter has been observed. For instance, Roscoe et al. (2001) assessed the replacement of a $\mathrm{C}_{3}$ Cerrado-type vegetation physiognomy by an exotic grass Brachiaria spp. $\left(\mathrm{C}_{4}\right)$. They found that higher replacement occurred at the first soil horizon (i.e. A horizon) where about $36 \%$ of the soil organic $\mathrm{C}$ was still derived from the $\mathrm{C}_{3}$ vegetation after 23 years of pasture cultivation (Roscoe et al. 2001). Our results, in turn, show that after approximately 13 to 60 years under $\mathrm{C}_{4}$ plants, a proportion of $25-30 \% \mathrm{C}_{3}$ derived carbon still can be found in the riparian areas of watersheds 1 and 2. Differences between the present study and the one by Vitorello et al. (1989) might be related to soil characteristics such as texture (Roscoe et al. 2001) or other factors affecting soil carbon turnover rate (Powers \& Schlesinger 2002; Telles et al. 2003) such as soil moisture that might be typically higher in riparian soils compared to upland soils (Luizão et al. 2004). Moreover, the long-term persistence of $\mathrm{C}_{3}$ signals in the riparian areas of watersheds 1 an 2 might be attributed to highly recalcitrant organic matter or organic matter that is tightly bound to clay soil particles (Roscoe et al. 2001, Powers \& Schlesinger 2002, Telles et al. 2003, Alcântara et al. 2004, Marin-Spiotta et al. 2009).

\section{Implications for riparian forest buffer width determination}

The fact that riparian areas of watersheds 1 and 2, and even watersheds 3 and 4 showed clear contributions of $\mathrm{C}_{4}$ derived carbon, may provide evidence that, in some cases, even riparian forest of 30 meters width or more are under strong influence of the upslope $\mathrm{C}_{4}$ cultivated areas. As a consequence, 30 meters riparian forest buffers or narrower widths (as currently allowed in 2012 Forest Act) do not appear to be appropriate to conserve soil and water. Indeed, a similar finding has been found in a nearby area where even 30 meters riparian buffers did not suffice to retain soil particles originated from sugarcane fields (Pires et al. 2009).

If the five cases presented here represent the variety of conditions by which riparian areas are subject in southeast São Paulo and other highly intensive agricultural landscapes elsewhere, it appears that, in most cases, riparian forest buffers of 30 meters or narrower might not be enough with regards to water resources protection. Thus, based on the 2012 Brazilian Forest Act, we expect that riparian areas with riparian forest buffers 5 to 15 meters wide will, in most cases, not be effective buffers to protect soil and water quality, the main original purpose of the Forest Act. Consequently, we expect the increases in suspended and bed load and their associated materials enhancing stream siltation, which in turn, alter light regime and stream environment with detrimental effects on stream water quality and biota.

\section{Conclusion}

We have shown that soil stable carbon isotopic composition can be a useful tool to investigate compliance with the Forest Act in riparian areas that were or are currently under the influence of a $\mathrm{C}_{4}$ vegetation type. As pasture soils in Brazil have approximately 200 million ha covered with exotic African $\mathrm{C}_{4}$ grasses, and an additional 24 million ha of corn and sugarcane crops together (Martinelli et al. 2010), the isotopic approach could be used to study several of these areas. However, for future studies it is imperative that soil sampling has to include deeper soil layers to exclude the influence of $\mathrm{C}_{4}$ carbon generated upland (i.e. outside of the riparian area).

Finally, narrower riparian forest buffers ( $<30$ meters) currently allowed in the 2012 Forest Act will likely contribute to keep the detrimental effects of soil erosion with consequences connected to stream water quality in agricultural landscapes. In other words, the already high stream suspended load and siltation with consequences for stream morphology, which shapes stream biota and nutrient uptake, are highly expected to remain in such landscapes where 30 native riparian forest buffer is no longer required.

\section{Acknowledgements}

The authors would like to thank George Lambais, Daniela Luz, César Piccirelli, Jean Carvalho and Juliana Gragnani for their precious help during the field campaigns and laboratory analysis. In addition, we wish to thank all of the technical staff of Isotope Ecology Lab CENA/USP. Jim Hesson of Academic EnglishSolutions.com revised the English. Finally, we thank the Coordenação de Aperfeiçoamento de Pessoal de Nível Superior (CAPES) and São Paulo Research Foundation (FAPESP; grant \#2014/10192-7) for the scholarship granted to M. Magioli.

\section{References}

ABERNETHY, B. \& RUTHERFURD, I.D. 2000. The effect of riparian tree roots on the mass-stability of riverbanks. Earth Surf Process Landforms 25:921-937. http://dx.doi.org/10.1002/10969837(200008)25:9<921::AID-ESP93 > 3.0.CO;2-7

ADAMI, M., RUDORFF, B.F.T., FREITAS, R.M., AGUIAR, D.A., SUGAWARA, L.M. \& MELLO, M.P. 2012. Remote sensing time series to evaluate direct land use change of recent expanded sugarcane 
crop in Brazil. Sustainability 4:574-585. http://dx.doi.org/10.3390/ su4040574

ALCÂNTARA, F.A., BUURMAN, P., FURTINI NETO, A.E, CURI, N. \& ROSCOE, R. 2004. Conversion of grassy cerrado into riparian forest and its impact on soil organic matter dynamics in an Oxisol from southeast Brazil. Geoderma 123:305-317. http://dx.doi.org/10.1016/j.geoderma.2004.02.014

ASSAD, E.D., PINTO, H.S., MARTINS, S.C., GROPPO, J.D., SALGADO, P., VASCONCELOS, E., SANO, E., PAVÃO, E., LUNA R., CAMARGO, P.B. \& MARTINELLI, L.A. 2013. Changes in soil carbon stocks in Brazil due to land use: paired site comparison and a regional pasture soil survey. Biogeosciences 10:5499-5533. http://dx.doi.org/10.5194/bgd-10-5499-2013

BRANCALION, P.H.S., INSERNHAGEN, I., GANDOLFI, S. \& RODRIGUES, R. Plantio de árvores nativas fundamentada na sucessão florestal. 2009. In: Pacto pela restauração da Mata Atlântica: referencial dos conceitos e ações de restauração florestal. LERF/ESALQ, Instituto BioAtlântica, São Paulo. p.14-23.

CAVALCANTI, G. \& LOCKABY, B.G. 2005. Effects of sediment deposition on fine root dynamics in riparian forests. Soil Sci Soc Am J, 69(3):729-737. http://dx.doi.org/10.2136/sssaj2004.0239

CAVALCANTI, G. \& LOCKABY, B.G. 2006. Effects of sediment deposition on aboveground net primary productivity, vegetation composition and structure in riparian forests. Wetlands, 26(2): 400-409. http://dx.doi.org/10.1672/0277-5212(2006)26[400:EOSDOA] 2.0.CO;2

COOK, L.R., STAPE, J.L. \& BINKLEY, D. 2014. Soil carbon dynamics following reforestation of tropical pastures. Soil Sci Soc Am J, 78:290-296. http://dx.doi.org/10.2136/sssaj2012.0439

COOPER, J.R., GILlIAM, J.W., DANIELS, R.B. \& ROBARGE, W.P. 1987. Riparian areas as areas of agricultural sediment. Soil Sci Soc Am J, 51(2):416-420. http://dx.doi.org/10.2136/sssaj1987. 03615995005100020029x

DE PAULA, F.R, FERRAZ, S.F.B, GERHARD, P, VETTORAZZI, C.A. \& FERREIRA, A. 2011. Large woody debris input and its influence on channel structure in agricultural lands of southeast Brazil. Environ Manage, 48(4):750-763. http://dx.doi.org/10.1007/ s00267-011-9730-4

FARQUHAR, G.D., EHLERINGER, J.R. \& HUBI, C.K. 1989. Carbon discrimination and photosynthesis. Annu Rev Plant Physiol Plant Mol Biol 40:503-537. http://dx.doi.org/10.1146/annurev. pp. 40.060189 .002443

GRISCOM, H.P., GRISCOM, W.G. \& ASHTON, M.S. 2009. Forest regeneration from pasture in the dry tropics of Panama: effects of cattle, exotic grass, and forested riparia. Restor Ecol 17(1): 117-126. http://dx.doi.org/10.1111/j.1526-100X.2007.00342.x

GUARANTINI, M.T.G., GOMES, E.P.C., TAMASHIRO, J.Y. \& RODRIGUES, R.R. 2008. Composição florística da reserva Municipal de Santa Genebra, Campinas, SP. Rev Bras Bot 31(2):323-337. http://dx.doi.org/10.1590/S0100-84042008000200015

HAWES, E. \& SMITH, M. 2005. Riparian buffer zones: functions and recommended widths. Eightmile River Wild and Scenic Study Committee. $15 \mathrm{p}$.

IMHOLT, C., SOULSBY, C., MALCOM, I.A. \& GIBBINS, C.N. 2013. Influence of contrasting riparian cover on stream temperature dynamics in salmonid spawning and nursery streams. Ecohydrology 6(3):380-392. http://dx.doi.org/10.1002/eco.1291

LOWRANCE, R., LEONARD, R. \& SHERIDAN, J.M. 1985. Managing riparian ecosystems to control nonpoint pollution. J Soil Water Conserv 40(1):87-91.

LOWRANCE, R., SHARPE, J.K. \& SHERIDAN, J.M. 1986. Longterm sediment deposition in the riparian zone of a coastal plain watershed. J Soil Water Conserv 41(4):266-271.

LUIZÃO, R.C.C., LUIZÃO, F.J., PAIVA, R.Q., MONTEIRO, T.F., SOUSA, L.S. \& KRUIJTS, B. 2004. Variation of carbon and nitrogen cycling processes along a topographic gradient in a central Amazonian forest. Glob Change Biol, 10:592-600. http://dx.doi.org/10.1111/j.1529-8817.2003.00757.x
MAMOLI, R.S., COOPER, M., TOMAZELO, M. \& LOBÃO, M.S. 2012. Aplicação da dendrogeomorfologia no estudo da deposição de sediments do solo no tronco de árvores de Guarea guidonea em mata ciliar no Estado de Goiás, Brasil. Sci For 40:7-14.

MARIN-SPIOTTA, E., SILVER, W.L. SWANSTON, C.W., OSTERTAG, R. 2009. Soil organic matter dynamics during 80 years of reforestation of tropical pastures. Glob Change Biol, 15:1584-1597. http://dx.doi.org/10.1111/j.1365-2486.2008.01805.x

MARTINELLI, L.A., JOLY, C.A., NOBRE, C.A. \& SPAROVEK, G. 2010. The false dichotomy between preservation of the natural vegetation and food production in Brazil. Biota Neotrop. 10(4):323-330. (in Portuguese), http://dx.doi.org/10.1590/S167606032010000400036

MARTINELLI, L.A., PESSENDA, L.C.R., ESPINOZA, E., CAMARGO, P.B., TELLES, E.C., CERRI, C.C., VICTORIA, R.L., ARAVENA, R, RICHEY, J.E. \& TRUMBORE S. 1996. Carbon-13 variation with depth in soils of Brazil and climate change during Quaternary. Oecologia 106:376-381. http://dx.doi.org/10.1007/ BF00334565

PIRES, L.F., BACCHI, O.O.S., CORRECHEL, V., REICHARDT, K. \& FILIPPE, J. 2009. Riparian forest potential to retain sediment and carbon evaluated by the ${ }^{137} \mathrm{Cs}$ fallout and carbon isotopic ratio approach. An Acad Bras Cienc 81(2):271-279. http://dx.doi. org/10.1590/S0001-37652009000200013

POWERS, J.S. \& SCHLESINGER, W.H. 2002. Geographic and vertical patterns of stable carbon isotopes in tropical rain forest soils of Costa Rica. Geoderma 109:141-160. http://dx.doi.org/10.1016/ S0016-7061(02)00148-9

ROSCOE, R., BUURMAN, P., VELTHORST, E.J. \& VASCONCELLOS, C.A. 2001. Soil organic matter dynamics in density and particle size fractions as revealed by the ${ }^{13} \mathrm{C} /{ }^{12} \mathrm{C}$ isotopic ratio in a Cerrados oxisol. Geoderma 104:185-202. http://dx.doi.org/ 10.1016/S0016-7061(01)00080-5

RUDORFF, B.F.T., AGUIAR, D.A., SILVA, W.F., SUGAWARA, L.M., ADAMI, M. \& MOREIRA, M.A. 2010. Studies on the rapid expansion of sugarcane for ethanol production in São Paulo State (Brazil) using Landsat data. Remote Sensing 2:1057-1076. http://dx.doi.org/10.3390/rs2041057

SCHOONOVER, J.E., WILLIARD, K.W.J., ZACZEK, J.J., MANGUN, J.C. \& CARVER, A.D. 2006. Agricultural sediment reduction by giant cane and forest riparian buffers. Water Air Soil Poll 169:303-315. http://dx.doi.org/10.1007/s11270-006-3111-2

SPAROVEK, G., BERNDES, G., KLUG, I.L. \& BARRETO, A.G. 2010. Brazilian agriculture and environmental legislation: status and future challenges. Environ Sci Technol 44(16):6046-6053. http://dx.doi.org/10.1021/es1007824

TELLES, E.C.C., CAMARGO, P.B., MARTINELLI, L.A., TRUMBORE, S.E., COSTA, E.S., SANTOS, J., HIGUCHI, N. \& OLIVEIRA Jr, R.C. 2003. Influence of soil texture on carbon dynamics and storage potential in tropical forest soils of Amazonia. Global Biogeochem Cy 17(2):1030-1040. http://dx.doi.org/10.1029/ 2002GB001953

VERSTRAETEN, G., POESEN, J., GILliJNS, K. \& GOVERS, G. 2006. The use of riparian vegetated filter strips to reduce river sediment loads: an overestimated control measure? Hydrol Process 20:4259-4267. http://dx.doi.org/10.1002/hyp.6155

VITORELlO, V.A., CERRI, C.C., ANDREUX, F., FELlER, C., VICTORIA, R.L. 1989. Organic matter and natural C-13 distribution in forested and cultivated oxisols. Soil Sci Soc Am J 53:773-778. http://dx.doi.org/10.2136/sssaj1989.0361599500 $5300030024 \mathrm{x}$

WENGER, S. 1999. A review of the scientific literature on riparian buffer width, extent and vegetation. Athens: University of Georgia. 59p.

YOO, K., AMUNDSON, R., HEIMASATH, A.M. \& DIETRICH, W.E. 2005. Erosion on upland hillslope soil organic carbon: coupling field measurements with a sediment transport model. Global Biogeochem Cyc 19:1-17. http://dx.doi.org/10.1029/ 2004GB002271 
Salemi, L.F. et al.

YUAN, Y; BINGNER, R.L. \& LOCKE, M.A. 2009. A review of effectiveness of vegetative buffers on sediment trapping in agricultural areas. Ecohydrol 2:321-336. http://dx.doi.org/10.1002/ eco. 82
ZHANG, K.; DANG, H.; ZHANG, Q. \& CHENG, X. 2015. Soil carbon dynamics following land-use varied with temperature and precipitation gradients: evidence from stable isotopes. GCB 21:2762-2772. http://dx.doi.org/10.1111/gcb.12886

Received 12/11/2015

Revised 31/05/2016

Accepted 02/06/2016 